\title{
$\alpha$-naphthylisothiocyanate による実験的肝内胆汁
}

\section{うっ滞の発生機序に関する研究}

\author{
高橋＼cjkstart裕*
}

要 旨: $\alpha$-naphthylisothiocyanate (ANIT) の肝内胆汁うつ滞発現機序を Sprague-Dawley ラット（SDR），ならびにその突然変異種である Eisai hyperbilirubinuria rat（EHBR）を用 い in vivo で検討した. SDR ANIT を経口投与すると肝内胆汁うっ滞を生じるが, 投与後早 期に肝総グルタチオン (GSH) 濃度は一過性に減少した。フェノバルビタール前処置にて肝総 GSH 濃度を増加させた SDR では, ANITによる胆汁うっ滞がより強くみられた. GSH 抱合体 の胆汁排泄障害が知られている EHBRに ANITを投与しても, 胆汁うっ滞は生じなかった. GSH 抱合体として胆汁中に排泄される bromosulfophthalein (BSP) と ANIT とを同時に持続 静注すると, BSP の胆汁排泄低下がみられた。これらの現象から, ANIT は GSH 抱合体とし て胆汁中に排泄され，胆汁うっ滞を引き起こすことが示唆された。

索引用語： $\alpha$-naphthylisothiocyanate (ANIT) グルタチオン 胆汁うっ滞 Eisai hyperbilirubinuria rat (EHBR)

\section{緒言}

$\alpha$-naphthylisothiocyanate (ANIT) は，ラットに容 量依存性に中毒性の肝内胆汁うっ滞を引き起こすこと から肝内胆汁うっ滞モデルの作製に広く使用されてい る. 投与約 12 時間後から胆汁流量は減少し, 組織学的 に胆管上皮の壊死, 細胆管増生, 門脈域周囲に軽度の 肝細胞障害を認めることなどを特徵としている ${ }^{1}$ 。し かし，その毒性の発現機序に関してはいまだ不明な点 が多い.

福本ら ${ }^{2}$ は ANIT 投与後, 肝細胞小胞体チトクロー ム P450が低下すること,フェノバルビタール前処置に て, 肝細胞小胞体チトクローム 4450 を誘導すると ANIT の肝障害が悪化することを報告し, ANIT の毒 性発現過程で, 肝細胞小胞体におけるチトクローム P450の関与を唱えている.しかし，チトクロームP450 系で生物学的に活性化され，肝障害を引き起こす薬剤 による肝組織病変の多くは, 中心静脈周囲の肝細胞壊 死を特徵とし ${ }^{3)}$ ANITによる肝障害の肝組織像とは異 なる。

最近 Carpenter ら (4) は, 分離肝細胞に ANITを加え ると, 肝細胞から総グルタチオン (GSH) の放出が起

Yutaka TAKAHASH *

*東邦大学第 2 内科

$<$ 受付日1996年 6 月 4 日 $>$
こり，肝細胞内の総 GSH は減少することを報告した， さらに, in vitro で GSH-ANIT 抱合体と思われる合 成体の形成が可能であること，その抱合体の結合は非 常に可逆的である事を見いだしたと報告した。この ANIT が肝細胞で GSH 抱合をうけ胆汁中に排泄され るという説は, 今まで不明であった ANIT 起因性の肝 内胆汁うっ滞の機序をかなり説明できると思われる. そこで今回，実際に in vivoでもそのような現象が起 きているかどうかを Sprague-Dawley rat (SDR) で検 討した。また, GSH 抱合体の胆汁排泄が障害されてい るSDR の変異種である Eisai hyperbilirubinuria rat （EHBR）を用い同様に検討し, SDR の成績と比較し た.

\section{実験材料および実験方法}

実験動物：SDR およびEHBR とも，雄性，体重250 $\mathrm{g}$ 前後を用いた。実験前は12時間の断食を行い, 実験の 間は室温 $25^{\circ} \mathrm{C}$ とラットの体温を一定に保った。各々 の実験でラットは 3 から 5 匹を用いた。

尚, EHBR はエーザイ株式会社川島工園より供与し て頂いた。

\section{実験方法}

実験 1：ANITによる肝内胆汁うっ滞の検討

\section{(1) ANIT の投与}

ANIT は, エーテル浅麻酔下のラットに経口的に 
PE50チューブを胃内に挿入し， $100 \mathrm{mg}(540 \mu \mathrm{mol}) / \mathrm{kg}$ 体重をサラダ油 $1 \mathrm{~m} l$ に溶解し一回投与した. ANIT 投 与の実験は以下の三群で行った.

1）フェノバルビタール前処置 SDR 群：ANIT 投 与に先立ち， $100 \mathrm{mg} / \mathrm{kg}$ 体重の $10 \%$ フ バルビター ルを SDRに 3 日間連日腹腔内に投与した。

2) 非前処置 SDR 群：フェノバルビタール非投与 の SDR

3) EHBR 群：フェノバルビタール非投与の EHBR

(2) 肝 GSH の測定

肝総 GSH の測定は, 非前処置 SDR 群およびフェノ バルビタール前処置 SDR 群に行った。各々ANIT 投 与前, 投与 $6,12,24,72$ 時間後に肝を摘出し, 門脈 から0.25M 塩化ナトリウムおよび $0.25 \mathrm{M}$ sucrose を 含む, $\mathrm{pH} 7.4$ の燐酸緩衝生食水 (PBS) で肝臟を洗浄 した．上記洗浄夜と同じバッファーを用い $25 \%$ ホモジ ネートを作製， 6 万 G，60分間の超遠心後，上清をグ リオキサラーゼ法占にて測定した。

\section{(3) 胆汁流量の測定}

胆汁流量の測定は，3群に行った。各々ANIT 投与 前, 投与 $6,12,24,72$ 時間後に, 総胆管に PE10チュー ブをカニュレーションし，胆汁を20分間全て採取し測 定した。

\section{（4）血液生化学検査}

3 群に対し, ANIT 投与前, 投与 $6,12,24 ， 72$ 時 間後に開腹後, 腹部大動脈加採血し,肝胆道系䤃素： alkaline phosphatase (ALP), $\gamma$ glutamyltranspeptidase $(\gamma-\mathrm{GTP})$, glutamate pyruvate transaminase (GPT), 総胆汁酸, 血清ビリ ルビン值を測定した。ALP は GSCC 準拠法, $\gamma$-GTP および GPT は IFCC 準拠法, 総胆汁酸は, $3 \alpha-\mathrm{HSD}$, $\Delta 4 \mathrm{DH}$ による酵素法, 血清ビリルビン值は, アルカリ アゾビリルビン法にて測定した。

\section{(5) 肝組織像}

肝組織像の光学顕微鏡観察は, 非前処置 SDR 群お よび EHBR 群で行った. ANIT 投与72時間後に肝を 摘出しホルマリン固定後の組織切片から hematoxylin \& eosin (H \& E) 染色標本を作製した.

実験 $2 ： \mathrm{BSP}$ の胆汁排泄へ及ほす ANIT の影響

SDR を, ペントバルビタール麻酔下に開腹し, 総胆 管にPE10チューブをカニュレーションした。 その後, 大腿静脈から生理食塩水を持続注入し, 胆汁流量の安 定した後に，BSP $0.7 \mu \mathrm{mol} / \mathrm{min} / \mathrm{kg}$ の持続静注を 120
分間行った。この間，胆汁は全量採取し，10分毎に流 量および BSP 濃度を測定した. BSP の胆汁排泄は, 投 与開始 10 分後から急速に増加し，40から50分以後はフ ラトーとなり最大排泄率 $(\mathrm{Tm})$ に達した。次に, BSP 持続静注開始後60分後から 70 分後にかけて, ANIT 50 $\mathrm{mg}(270 \mu \mathrm{mol}) / \mathrm{kg}$ 体重を加熱溶解した静注用脂肪乳 剤 (イントラリピット) $1 \mathrm{~m} l$ を10分間, BSP と同時に 持続静注した，同様に，イントラリピット $1 \mathrm{~m} l$ 単独の 持続静注も行い対照とした。上記のごとく10分毎に胆 汁を採取し流量および BSP 濃度を測定した。

統計処理：同時期における群間の検討には, Student $\mathrm{t}$ 検定を用いた。また，同群の経時的な検討には Scheffe の検定を用いた。いずれも危険率 $5 \%$ 末満を 有意とした。

\section{成 績}

（1）肝総 GSH 濃度の変化（Fig. 1)

ANIT 投与前肝総 GSH 濃度は，フェノバルビター ル非前処置 SDR 群の $4.62 \pm 0.51 \mu \mathrm{mol} / \mathrm{g}$-liver に比

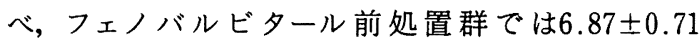

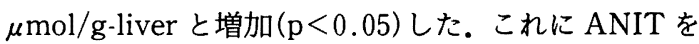
投与すると，非前処置群では，投与 6 時間後に有意 $(\mathrm{p}<0.05)$ に減少し，12時間後に回復，その後増加し

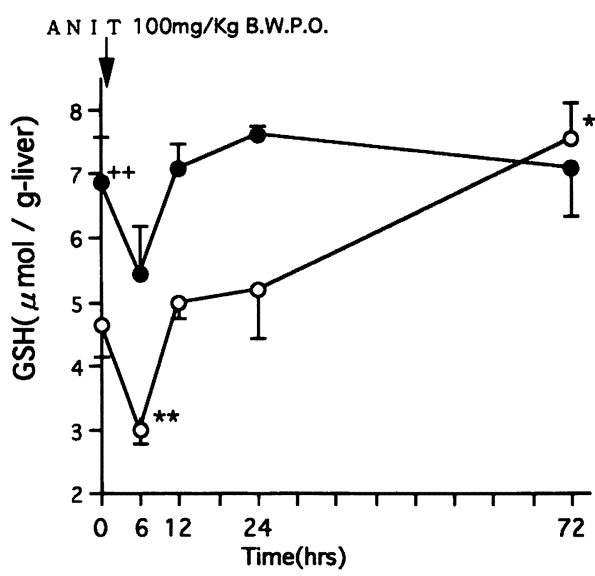

Fig. 1 Changes in the concentration of glutathione (GSH) in the liver homogenate after oral administration of $\alpha$-naphthylisothiocyanate (ANIT), $100 \mathrm{mg}(540 \mu \mathrm{mol}) / \mathrm{Kg}$ B.W., in SpragueDawley rats (SDR) with (-O) or without (-O-) the pretreatment of phenobarbital. Each value represents the mean \pm SD. ${ }^{*} \mathrm{p}<0.01 ;{ }^{* *} \mathrm{p}<$ 0.05 compared with the basal levels before the administration of ANIT. ${ }^{++} p<0.05$ compared with the levels of non-pretreated SDR. 
た.フェノバルビタール前処置群でも, 投与 6 時間後 に減少し, その後増加した。

(2) 胆汁流量の变化 (Fig. 2)

ANIT 投与前胆汁流量は,フェノバルビタール前処

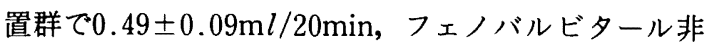
処置群で $0.55 \pm 0.04 \mathrm{ml} / 20 \mathrm{~min}$ と, 両群に有意差はな かった. EHBR 群は, $0.167 \pm 0.07 \mathrm{~m} l / 20 \mathrm{~min}$ と非処置 群に比し有意 $(p<0.01)$ に減少していた. ANIT 投与 後の胆汁流量の変化は, 非処置の SDR では, 投与前平 均 $0.55 \pm 0.04 \mathrm{ml} / 20$ 分, 投与 24 時間後 $0.04 \pm 0.003 \mathrm{ml} /$ 20 分と有意 $(p<0.01)$ な減少であった。一方, 前処置 群では ANIT 投与前 $0.49 \pm 0.09 \mathrm{~m} l / 20$ 分から12時間 後には, すでに $0.004 \pm 0.002 \mathrm{ml} / 20$ 分と, 有意 $(\mathrm{p}<$ 0.01）に減少し, 両群とも72時間後には回復の傾向が うかがえた。しかし，EHBR 群では，ANIT 投与後の 胆汁流量の減少は認められなかった。

（3）血液生化学検査, 肝組織像の変化

a）血液生化学検査：ANIT 投与前の血清中の肝胆 道系醉素 (ALP， $\gamma$-GTP，GPT)，および総胆汁酸濃 度は, 各群に有意差を認めなかったが, ANIT 投与後, フェノバルビタール前処置群では非処置群に比べより 早期から上昇した。すすなち，GPT は 12 時間後， $\gamma$ GTP は12時間後, 総胆汁酸も 12 時間後より著明に上昇 した.しかし，EHBRではこのような所見は認められ なかった (Table).

b) 肝組織像：フェノバルビタール非前処置 SDR ならびに EHBR 群の ANIT 投与72時間後の肝組織像

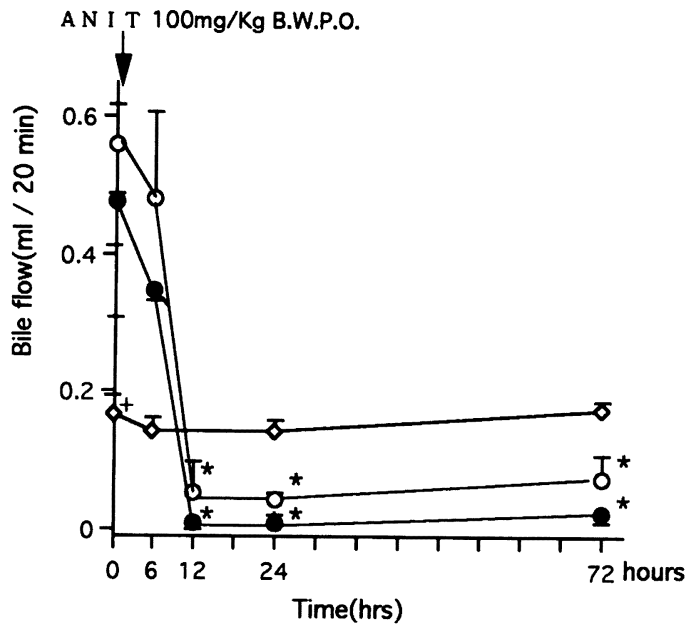

Fig. 2 Changes in bile flow $(\mathrm{m} l / 20 \mathrm{~min})$ after the oral administration of ANIT, $100 \mathrm{mg}(540 \mu \mathrm{mol}) /$ $\mathrm{Kg}$ B.W., in SDR with (- -) or without (- - ) the pretreatment of phenobarbital, and in Eisai hyperbirilubiuria rats (EHBR - ). Each value represents the mean \pm SD. ${ }^{*} \mathrm{p}<0.01$ compared with the value basal levels before the administration of ANIT. ${ }^{+} \mathrm{p}<0.01$ compared with the levels in the non-pretreated SDR.

は，SDR では胆管の壊死，細胆管の増生，門脈域周囲 に軽度の肝細胞障害を認めるが, EHBR においては, このような所見は認められなかった（Fig. 3).

Table Changes in serum levels of GPT, ALP, $\gamma$-GTP, and bile acids after the administration of ANIT in SDR with or without pretreatment of phenobarbital and in EHBR. Each value represents the mean $\pm \mathrm{SD}$.

\begin{tabular}{cc|c|c|c|c|c}
\hline & & 0 & 6 & 12 & 24 & 72 hours \\
\hline & SDR & $77 \pm 20$ & $147 \pm 114$ & $91 \pm 8$ & $537 \pm 185$ & $983 \pm 293^{*}$ \\
GPT & SDR + PB & $135 \pm 54$ & $453 \pm 14$ & $873 \pm 100^{*}$ & $1,379 \pm 327^{*}$ & $447 \pm 100$ \\
& EHBR & $111 \pm 57$ & $44 \pm 11$ & n.d. & $97 \pm 14$ & $230 \pm 3$ \\
\hline & SDR & $791 \pm 156$ & $650 \pm 72$ & $808 \pm 60$ & $1,150 \pm 356$ & $1,882 \pm 283^{*}$ \\
ALP & SDR + PB & $571 \pm 69$ & $453 \pm 14$ & $1,330 \pm 262$ & $1,365 \pm 477$ & $1,299 \pm 358$ \\
$(\mathrm{U} / \mathrm{L})$ & EHBR & $539 \pm 11$ & $531 \pm 75$ & n.d. & $612 \pm 69$ & $707 \pm 98$ \\
\hline & SDR & $0.7 \pm 0.5$ & $0.7 \pm 0.9$ & $5.0 \pm 0.5$ & $4.0 \pm 2.2$ & $1.8 \pm 14.3$ \\
$\gamma$-GTP & SDR+PB & $0.3 \pm 0.5$ & $4.3 \pm 3.4$ & $6.7 \pm 0.5^{* *}$ & $5.5 \pm 1.1$ & $3.0 \pm 1.6$ \\
$(\mathrm{U} / \mathrm{L})$ & EHBR & $0.5 \pm 0.5$ & $0.5 \pm 0.5$ & n.d. & $0.8 \pm 0.8$ & $1.0 \pm 1.2$ \\
\hline & SDR & $20 \pm 10$ & $10 \pm 7$ & $637 \pm 426$ & $790 \pm 296$ & $438 \pm 99$ \\
Bile Acids & SDR+PB & $22 \pm 7$ & $414 \pm 283$ & $765 \pm 145^{* *}$ & $803 \pm 247^{*}$ & $573 \pm 31$ \\
$(\mu$ M $)$ & EHBR & $52 \pm 5$ & $23 \pm 14$ & n.d. & $62 \pm 38$ & $142 \pm 59$ \\
\hline
\end{tabular}



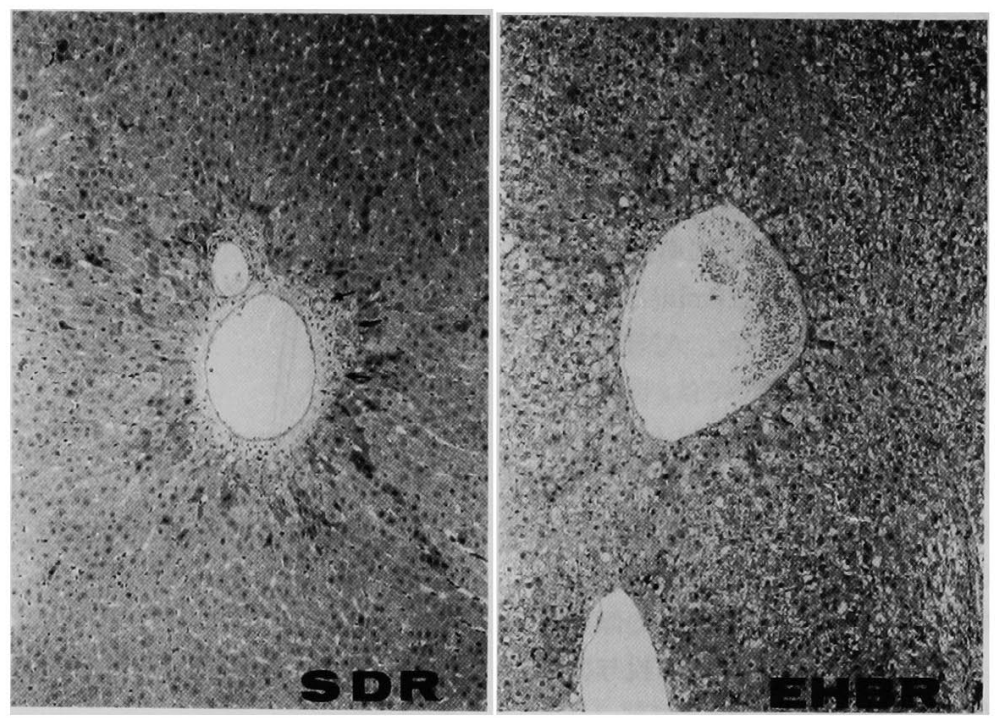

Fig. 3 Histological findings of the liver 3 days after the oral administration of ANIT, $100 \mathrm{mg}(540 \mu \mathrm{mol}) /$ B.W., obtained from SDR (left) and EHBR (right). Degenerative changes of the bile ducts and cholangiolar proliferations (arrows) were observed in the liver of SDR, while those findings were not observed in the EHBR. (HE, $\times 200)$.

（4）血清総ビリルビン值の変化（Fig. 4)

フェノバルビタール前処置群は非処置群に比べ投与

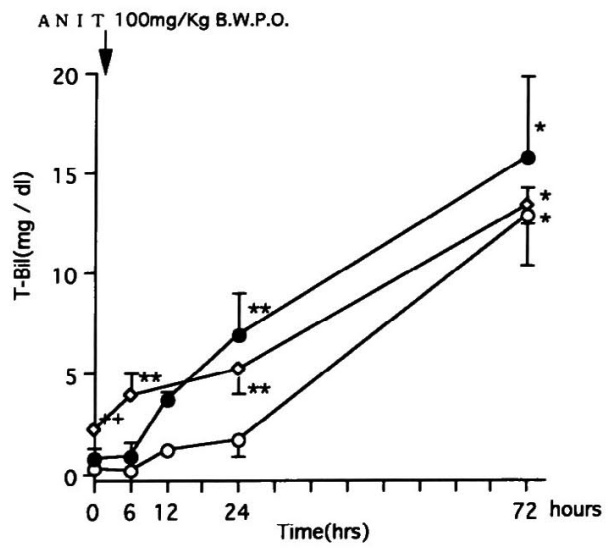

Fig. 4 Changes in serum levels of birilubin after the oral administration of ANIT, $100 \mathrm{mg}(540$ $\mu \mathrm{mol}) / \mathrm{Kg} \mathrm{B} . \mathrm{W}$., in SDR with (--) or without $(-\mathrm{O}-$ ) the pretreatment of phenobarbital and in EHBR $(\neg)$. Each value represents the mean \pm SD. ${ }^{*} \mathrm{p}<0.01 ;{ }^{* *} \mathrm{p}<0.05$ compared with the basal levels before the administration of ANIT. ${ }^{++} \mathrm{p}<0.05$ compared with the levels in the non-pretreated SDR.
24 時間後の早期から血清総ビリルビン值の有意 $(\mathrm{p}<$ $0.05)$ な上昇を認めた. EHBR では, 投与前から $2.2 \pm$ $0.3 \mathrm{mg} / \mathrm{d} l$ と黄疸を認めるものの, ANIT 投与 6 時間

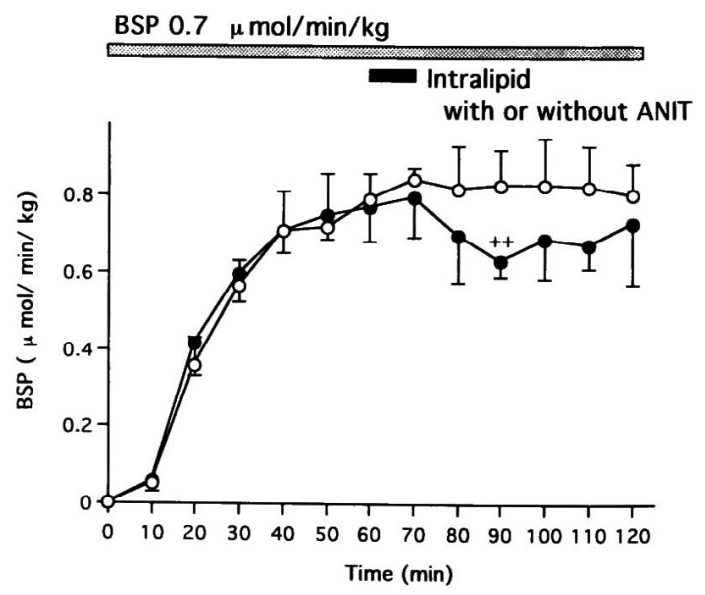

Fig. 5 Effect of co-infusion of ANIT, 50mg (270 $\mu \mathrm{mol}) / \mathrm{Kg}$ B.W. (- -), on excretion of BSP into the bile during continuous intravenous infusion of BSP in the SDR. -O- : control (intralipid without ANIT). Each value represents the mean \pm SD. ${ }^{++} p<0.05$ compared with the levels in the non-infusion of ANIT. 
後には $3.9 \pm 1.1 \mathrm{mg} / \mathrm{d} l$ と有意 $(\mathrm{p}<0.01)$ に上昇し，投 与 72 時間後では $13.8 \pm 0.37 \mathrm{mg} / \mathrm{d} l$ と, SDR と同様の 高值を示した，尚，いずれの時点でも直接型ビリルビ ンが総ビリルビンの約 $90 \%$ を示した。

(5) 胆汁中 BSP 濃度の变化（Fig. 5)

BSP の胆汁排泄が Tmに達した後, 10分間 ANIT を同時に持続静注すると，その後胆汁中 BSP 濃度は 徐々に低下し，20分後には有意 $(\mathrm{p}<0.05)$ な排泄低下 を示した．尚，イントラリピット単独投与では，BSP の排泄低下は認めなかった。

\section{考 案}

薬剤性肝障害においては, 高度の肝内胆汁うつ滞を きたすが肝細胞障害は非常に軽微である例がある。こ のような肝内胆汁うっ滞の機序に関してはいまだ十分 解明されていない. 古くから肝内胆汁うっ滞モデル動 物の作製に用いられている ANIT の毒性,すなわち肝 内胆汁うっ滞の発現機序に関しても同様に不明な点が 多い.本研究は,この点に関し in vivo の実験で, ANIT が肝細胞内で GSH 抱合を受け胆汁中に排泄される可 能性を指摘した。

Hirota $ら^{6}$ は閉塞性黄疸ラットを用いた実験で，胆 汁うっ滞時には経時的に肝 GSH は增加すると報告し ている.しかし本研究では, SDRに ANIT を経口投与 すると，胆汁うっ滞がいまだみられない早期，すなわ ち投与 6 時間後に肝総 GSH の一過性の低下がみられ た。したがって，この一過性の肝 GSH 濃度の低下は, 胆汁うっ滞の結果として生じたとは考えられず, ANIT による肝 GSH の減少, 即ち ANIT と GSH と の直接的な関係を示唆するものと思われる. Carpenter ら ${ }^{4} は$ は, ラットの分離肝細胞に ANIT 処理し, 細胞 障害を伴わない GSH の細胞内から培養液中への移行 を認めたと報告している.したがって，今回の肝 GSH 濃度の低下の原因は, GSH の合成障害ではなく, GSH が消費されるためあるいは細胞外に分泌されるためと 推察される.

今回の実験で, フェノバルビタール前処置群で, 胆 汁流量の低下, 血清ビリルビン值の上昇, 血清肝・胆 道系醅素の上昇などが，非前処置 SDR 群の場合に比 し,より早期からより強く出現した.フェノバルビター 儿前投与にて ANITによる肝内胆汁うっ滞がより強 くなる事実は以前から指摘されている7). フェノバル ビタールはチトクロームP450系の酵素の誘導剤であ ること卑から, ANIT は肝チトクローム P450で生物学 的活性を受け，毒性を発揮するものと考えられている。
アセトアミノフェンに代表される,チトクローム P450 系で生物学的に活性化され肝障害を引き起こす薬剤に よる肝組織病変の多くは，中心静脈周囲の肝細胞壊死 を特徴としている3).一方, ANITによる肝障害の肝組 織像は, 今回の実験でもみられたごとく, 胆管の壊死, 細胆管の増生が主体であり，肝細胞障害は門脈域周囲 に軽度に認められるのみ1である。このことから,フェ ノバルビタールによる ANIT 肝内胆汁うっ滞の増強 は,チトクローム P450系酵素の誘導のみでは説明でき ないと思われる.

一方,フェノバルビタールは，P450系酔素のみなら ずグルタチオン-S.トランスフェラーゼや GSH を誘導 することも知られている ${ }^{8)}$. 実際, 今回の実験において も,フェノバルビタール前処置 SDR の肝 GSH 濃度 は, 非前処置 SDR の值に比し約1.5倍増加していた。 ANIT が肝細胞内で GSH 抱合を受け胆汁中に排泄さ れるという仮定から考えれば，フェノバルビタールに よる肝 GSH の増加が, ANITあるいはANIT の P450代謝産物による肝細胞障害を防御し，一方で胆管 細胞障害すなわち胆汁うつ滞を増悪させている可能性 が考えられる，実際，グルタチオン合成酵素である $\gamma$-glutamylcysteine synthetase を阻害する buthionine sulfoximine を前投与し肝 GSH を低下させる と, ANITによる胆汁うっ滞が軽度になるという事実 も報告されている9 .

BSP は肝細胞で GSH 抱合を受け，大部分が BSP$\mathrm{SG}$ として胆汁中へ排泄される. 今回, この BSP と ANIT との同時静注を試みた。その結果, ANIT 静注 と一致して BSP の胆汁排泄の低下が観察された。こ のことは, BSP-SG の胆汁排泄が ANIT により障害を 受けることを示していると考えられる，尚，ANIT は 脂溶性であるためイントラリピットを溶解液剤とし た。このような ANIT の投与法は調べ得た限りでは報 告されていないので，本剤の胆汁中への BSP 排泄へ の影響も考慮しなければならない。そのため，同じ条 件下でイントラリピットのみの同時静注を試みた。そ の結果，BSP の胆汁中への排泄は低下せず，本剤の影 響は否定してょいと思われる。

ANIT と類似した構造式を持つbenzyl, allylisothiocyanate は, GSH 抱合を受けることが in vitro で明ら かにされている ${ }^{10)}$. 今回の実験から得られた in vivo における，(1）ANITによる肝 GSH 濃度の一過性の 低下，(2）フェノバルビタール前投与による肝 GSH の増加ならびに胆汁うっ滞の増強，（3）ANIT 同時静 
注による BSP-SG の胆汁排泄低下は，いずれも直接的 な証明ではないが, in vivo でも ANIT がGSH 抱合を 受けGSH-ANIT 抱合体として胆汁中に排泄される可 能性を支持するものである.

EHBR は, SDR の突然変異種であり, ヒトにおける Dubin-Johnson 症候群に類似したモデルと考えられ ている11).このモデル動物では, ビリルビン, BSP な ど種々の有機陰イオンをはじめ, GSH および GSH 抱 合体ならびに一部の胆汁酸などの胆汁中への排泄障害 が明らかにされており，その原因として， canalicular multi-specific organic anion transporter (cMOAT) の障害が考えられてきた ${ }^{12 \sim 14)}$. 最近, Ito らは, EHBR における cMOAT の欠損を遺伝子学的に証明してい $3^{15)}$.その EHBRに ANIT を投与したところ, 直接型 ビリルビンの血中増加はみられたが，胆汁うっ滞，す なわち胆汁流量の減少は全く認められず，また肝・胆 道系酵素の血中増加もみられず, 肝組織像においても, SDR でみられた胆管障害が認められなかった。これら の成績から，EHBRにおいてはANITまたはその代 謝物が胆汁中へ排泄されていないと推察される。一方 SDR では，放射標識を用いた実験で胆汁中に ANIT が排泄されることが証明されている ${ }^{16)}$.これらより， ANIT はGSH 抱合を受け胆汁中に排泄されたのち, 胆汁うっ滞を引き起こすものと思われる.

EHBR では, ANIT 投与後に, SDR と同程度の高直 接型ビリルビン血症が生じたが,これは前述のごとく 肝・胆道系酸素および胆汁酸の血中増加も, 組織学的 な胆管細胞障害も伴わず, SDR における胆汁うっ滞と 異なる機序によるものと思われる.EHBR で障害され ている cMOAT で，抱合型ビリルビンと ANIT の胆 汁排泄抱合体，すなわち GSH-ANIT 抱合体とが競合 的に関係しあい，その結果，抱合型ビリルビンの類洞 側への efflux が増加したものと考えられる.

本研究では, ANIT の肝内胆汁うっ滞の発生機序と して, ANIT が肝内で GSH 抱合を受け胆汁中に排泄 され，そこで細胆管障害を引き起こすことが示唆され た.そもそも GSH 抱合は, 肝における解毒機能の一つ として生体防御に重要な役割を担っている. したがっ て，ANIT に関してはこの GSH 抱合がむしろ毒性の 発現に関与するということは奇異にも感じられる。し かし bleomycine や necarziostatinなど, その GSH 抱合体がより強い毒性を有する物質も報告されてお $\eta^{17)}$, GSH-ANIT 抱合体が胆管上皮細胞に対し障害 性に働く可能性も考えられる。 また，胆汁中に排泄さ
れた GSH 抱合体は, 胆管, 小腸, 腎の上皮組織で $\gamma$. GTP などの酵素の働きにより cysteinylglycine-抱合 体,さらに cysteine-抱合体を経てメルカプール酸とし て尿中に排泄される.したがって, GSH-ANIT 抱合体 が胆汁中に排泄されると仮定した場合，それは胆汁中 で cysteinylglycine-ANIT 抱合体あるいは cysteineANIT 抱合体に代謝されるものと思われる. GSH 抱 合体が $\gamma$-GTP などにより，腎毒性を有する cysteine抱合体に代謝されることも報告されており cysteinylglycine-ANIT あるいは cysteine-ANIT の 抱合体が，胆管上皮細胞に対し障害性を有する可能性 も考えられる。また， Carpenter ら"が in vitro で作成 した GSH-ANIT 抱合体と思われる結合体は，非常に 可逆的であり，高濃度の GSH の存在下でのみ結合を 維持できたと報告されている.ラットの胆汁中 GSH の濃度に関しては, $\gamma$-GTP 阻害剤使用下では肝細胞中 の GSH 濃度とほほ同程度であったと報告されてい $3^{19)}$ が, 一方, 生理的条件下では肝細胞中の GSH 濃度 の約 3 分の 1 で $2 \mathrm{mM}$ 前後であったとの報告もみられ る ${ }^{20)}$. ANIT あるいはその P450代謝産物が, 肝細胞内 では GSH 抱合を受けるため毒性を発現しないが，胆 汁中においては GSH の濃度差あるいはそれ以外の理 由で脱抱合を受け, 遊離した ANIT が胆管上皮細胞の 障害を引き起こす可能性も否定できないと思われる。

\section{結語}

in vivo の実験で以下の結果を得た。

1）SDR に ANIT を投与すると一過性の肝 GSH 濃 度の低下がみられた。2) フェノバルビタール前処置に て肝総 GSH 濃度を増加させた SDR では, ANIT によ る胆汁うっ滞がょり強くみられた。3）EHBRに ANIT を投与しても，胆汁うっ滞は生じなかった。 4) BSP と ANIT とを同時持続静注すると, BSP の胆汁 排泄低下がみられた。

以上から, ANIT は GSH 抱合体として胆汁中に排 泄され，胆汁うっ滞を引き越こすことが示唆された。

謝辞：本稿を終わるにあたり，御校閲を賜りました東邦 大学第 2 内科学教室磯貝 庄教授に深謝いたします.また, 直接ご指導いただきました住野泰清助教授および山室 渡 講師に感謝いたします.

\section{文献}

1) Desmet VJ, Krstulovic B, Damme B: Histochemical study of rat liver in alphanaphthylisothiocyanate (ANIT) induced cholestasis. Am 
J Pathol $52: 401-421,1968$

2) 福本陽平, 沖田極, 竹本忠良, 他: Alphanaphthylisothiocyanate による実験的胆汁うっ滞 の発現と肝細胞小胞体中および核中の cytochroma P-450 の変動. 肝臟 $22: 552-558,1981$

3) Dahlin DC, Miwa GT, Nelson SD, et al: $\mathrm{N}$-acetyl-p-benzoquinone imine: A cytochrome P.450-mediated oxidation product of acetaminophen. Proc Natl Acad Sci (USA) 81 : 1327-1331, 1984

4) Carpenter L, Marchand DH, Reed DJ : Involvement of glutathione in 1 . naphthylisothiocyanate (ANIT) metabolism and toxicity to isolated hepatocytes. Biochem Pharmacol 42: 2171-2180, 1991

5) Williams $\mathrm{CH} \mathrm{Jr}$ : In : The Enzymes (ed. Boyer PD), XIII, p90, Academic Press, New York (1976)

6) Hirota $M$, Sugi $K$, Inoue $M$ : Dynamic aspects of glutathione metabolism in obstructive jaundice. J Gastroenterol 29: 588-592, 1994

7) Roberts RJ, Plaa GL: Potentiation and inhibition of $\alpha$-naphthylisothiocyanate induced hyperbilirubinemia and cholestasis. J Pharmacol Exp Therap 150:499-506, 1965

8) Kaplowitz N, Kuhlenkamp J, Reeve LJ, et al : Effect of salicylates and phenobarbital on hepatic glutathione in the rat. J Pharmacol Exp Therap 212:240-245, 1980

9) Dahm LJ, Roth RA: Protection aganist $\alpha$ naphthylisothiocyanate induced liver injury by decreased hepatic non-protein sulfhydryl content. Biochem Pharmacol 42: 1181-1189, 1991

10) Bruggeman IM, Temmink JHM, Bladeren PJ : Glutathione- and cysteine-mediated cytotoxicity of allyl and benzyl isothiocyanate. Toxicol Appl Pharmacol 83 : 349-359, 1986

11) Mikami $T$, Tagaya $S$, Ohgoh $T$, et al: The character of a new mutant in rats with hyperbilirubinuria syndrome. Congenital Anom 26: $250-251,1986$
12) Takikawa H, Sano N, Tagaya O, et al: Biliary excretion of bile acid conjugates in a hyperbilirubinemic mutant Sprague-Dawley rat. Hepatology $14: 352-360,1991$

13) Kurisu H, Kamisaka K, Tagaya O, et al: Organic anion transport study in mutant rats with autosomal recessive conjugated hyperbilirubinemia. Life Sci 49 : 1003-1011, 1991

14) Oude Elferink RPJ, Ottenhoff R, Jansen PLM, et al: Hepatobiliary transport of glutathione and glutathione conjugate in rats with hereditary hyperbilirubinemia. J Clin Invest $84: 476-$ 483, 1989

15) Ito $K$, Suzuki $H$, Hirohashi $T$, et al: Expression of a putative ATP-binding cassette region, homologous to that in multidrug resistanceassociated protein (MRP), is hereditarily defective in Eisai hyperbilirubinemic rats (EHBR). Int Hepatol Commun 4:291-298, 1996

16) Capizzo F, Robert J: Disposition of the hepatotoxin $\alpha$-naphthylisothiocyanate (ANIT) in the rat. Toxicol Appl Pharmacol $17: 262-271$, 1970

17) Igwe OJ : Commentary. Biologically active intermediates generated by the reduced glutathione conjugation pathway. Toxicological implications. Biochem Pharmacol 18: $2987-$ 2994, 1986

18) Monks TJ, Lau SS: Commentary: Renal transport processes and glutathione and glutathione conjugate-mediated nephrotoxicity. Drug Metab Dispos 15: 437-441, 1987

19) Lu CS, Kuhlenkamp J, Sun WM, et al : Alterations in glutathione homeostasis in mutant Eisai hyperbilirubinemic rats. Hepatology 24 : 253-258, 1996

20) Lauterburg BH, Smith $C V$, Hughes $H$, et al : Biliary excretion of glutathione and glutathione disulfide in the rat regulation and response to oxidative stress. J Clin Invest 73 : $124-133,1984$ 


\section{Experimental analysis of the mechanisms of alpha- naphthylisothiocyanate-induced cholestasis in rats}

Yutaka TAKAHASHI*

To clarify the precise mechanism of intrahepatic cholestasis by alphanaphthylisothiocyanate (ANIT), ANIT was administered $(540 \mu \mathrm{mol} / \mathrm{kg})$ to Sprague-Dawley rats (SDR) and Eisai hyperbilirubinuria rat (EHBR). EHBR is known as a model animal of DubinJohnson syndrome, characterized by the impaired glutathione (GSH) and GSH-conjugated tansport via bile canalicular membranes. In SDR, the concentration of GSH in the liver tissue transiently decreased at 6 hours after oral administration of ANIT, followed by intrahepatic cholestasis. Moreover, pretreatment with phenobarbital enhanced the ANIT-induced cholestasis. On the other hand, ANIT did not cause cholestasis in EHBR, indicating impaired excretion of ANIT metabolites. In addition, the biliary excretion of sulfobromophtalein decreased when ANIT was co-infused. These results strongly suggest that ANIT may be excreted into the bile as a GSH conjugated form, and that GSH-conjugated ANIT oritsdeconjugates may cause cholestasis.

\footnotetext{
* Second Department of Internal Medicine, Toho University School of Medicine (Tokyo)
} 